\title{
O BOM PATRÃO E O INIMIGO VORAZ: PREDAÇÃO E COMÉRCIO NA COSMOLOGIA PAUMARI*
}

Oiara Bonilla

Quelle dérision, quel humour, quelle révolte invincible, quel triomphe se cachent sous un moi qui se déclare si faible? (Gilles Deleuze 1967)

Os Paumari habitam os lagos e as margens do médio rio Purus, no sul do estado do Amazonas. Falam uma língua arauá e são hoje aproximadamente mil pessoas, que vivem em três grandes áreas do médio Purus. Cerca de 700 pessoas habitam a região do Lago Marahã, uma centena vive nas margens do Rio Ituxi (afluente direito do Purus) e 200 pessoas aproximadamente vivem nos lagos do rio Tapauá, afluente esquerdo do Purus (a jusante de Lábrea). Os Paumari dessas três regiões falam variações da mesma língua. A língua paumari vem sendo estudada desde o final do anos 1960 pelas missionárias da Sociedade Internacional de Lingüística (ex-Summer Institute of Linguistics). No cotidiano, os Paumari usam freqüentemente o português (jara athini) para se comunicar entre si, associando geralmente estruturas frasais em português e vocabulário paumari formando uma sorte de 'pidgin', ininteligível para aqueles que não têm domínio da língua paumari (ariathi) ${ }^{1}$. Os Paumari vivem principalmente da pesca e da colheita, plantam roçados pequenos onde cultivam várias espécies vegetais, mas principalmente mandioca, cará e bananas. Também costumam plantar nas praias, durante o verão amazônico, e procuram comercializar boa parte dessa colheita com os regatões ou patrões em Lábrea.

Este texto é um ensaio etnográfico no qual duas observações feitas no campo servem como base para uma reflexão sobre a sociologia relacional Paumari. A primeira observação é a da insistência dos Paumari em transformar as relações com Outros em relação comercial (entre patrão e freguês, ou patrão e empregado), sejam eles outros índios (joima), vizinhos apurinã (viporina), regionais (jara), estrangeiros (americano) ou até parentes provenientes 
de algum grupo local mais distante. A segunda observação a ser explorada é a da descrição que os Paumari fazem de si mesmos, sempre como presas ou vítimas nas relações com Outros, sejam estes índios vindos de longe para devorá-los ou brancos vindos para matá-los ou escravizá-los.

Conhecendo a história da região e sabendo que os Paumari estiveram envolvidos (e até certo ponto ainda estão) na economia do aviamento instaurada no Purus no final do século XIX, com o surto da borracha, nenhuma das duas observações é surpreendente. Recém-chegada no campo pensei, em um primeiro momento, estar simplesmente frente àquela situação com a qual todo antropólogo pode se deparar hoje em dia: a de ser considerado imediatamente como mais um agente de contato que se torna rapidamente um provedor de bens manufaturados. Isso, sem dúvida, aconteceu e teve seu papel em tudo o que será exposto aqui.

Excetuando o fato de que tudo absolutamente era negociado e tinha de sêlo (seja em troca de dinheiro, seja em troca de mercadorias), o que também me chamou a atenção foi o desinteresse que, na maioria das vezes, os Paumari manifestavam pelos bens obtidos em troca de um favor, de uma informação, de um peixe etc. Tudo se passava como se fosse mais interessante cobrar algo do que obtê-lo realmente. Além de barganhar absolutamente tudo, os Paumari insistiam em se oferecer para me servir, colocando-se sistematicamente a meu serviço e transformando, às vezes, simples perguntas em ordens ou pedidos que deveriam ser devidamente remunerados ou compensados.

Por outro lado, eles se queixavam constantemente de suas condições de saúde e de vida atuais, opondo-as muitas vezes ao tempo dos patrões ou das missionárias do SIL2 ${ }^{2}$ Eu tinha, então, a impressão de estar diante de uma realidade que correspondia em tudo às idéias das teorias do contato e da aculturação.

Mas a descrição de si mesmos como vítimas e a "comercialização" das relações eram temas tão recorrentes no dia-a-dia, que se reencontravam em todas as minhas observações, sob várias formas. Pareceu-me, então, interessante ver isso de mais perto e ouvir o que os Paumari tinham a dizer sobre a sua condição histórica de vítimas, assim como tentar entender melhor essa obsessão pela negociação e pela troca comercial associada ao serviçalismo - que até então eu relacionava ao contato e à inserção histórica dos Paumari na economia da região.

\section{Os índios malhados}

A primeira observação mencionada no início deste ensaio diz respeito à comercialização das relações e mais especificamente ao interesse manifestado 
pelos Paumari em colocar-se na posição de empregados em toda relação com um Outro. O interesse dos Paumari pelo comércio já havia sido descrito pelos primeiros viajantes que exploraram o Purus, a partir da segunda metade do século XIX. Essa facilidade para comerciar também coincide em grande medida com a descrição destes índios como pacíficos ou medrosos e como grandes apreciadores do canto.

Naquela época, os Paumari, ou Pammarys, assim como os Juberi, eram ainda conhecidos como os Puru-Puru, os índios malhados, pois sofriam de uma doença de pele endêmica: a pinta ${ }^{3}$. Viviam em casas flutuantes nas margens e lagos do Baixo e Médio Purus e já eram descritos então como seres pacíficos, inofensivos, que gostavam de cantar e eram hábeis comerciantes. No rio Jacaré começava:

[...] o território dos índios Paumarys, que, com os Juberys, são meras subdivisões da antiga tribu dos Purú-Purús, nome este que se acha extinto. Fallam a mesma línguagem; têm os mesmo hábitos e a mesma apparencia, e são igualmente affectados de uma doença de pelle muito desagradável [...]. Os Paumarys são muito pacíficos, sendo quasi desconhecidas entre elles as mortes por violencia, e mesmo ferimentos e pancadas graves. São alegres, folgazões e amigos de cantar [...]. Alguns negociantes que têm empregado uma aldeia inteira deles, tiraram 200 a 300 tartarugas em um só dia de trabalho. [...] Eles recusam hoje os machados portugueses e querem os americanos; comerciam com outras tribus, vendendo-lhes facas usadas, machados, e são muito imitadores em seu gosto (Chandless 1949:26).

Labre, por sua vez, descreve-os como "'verdadeiros canoeiros' que fazem trabalhos de extracção de productos naturaes, que trocam por mercadorias e bebidas [...]" (Labre 1872:27).

Já Silva Coutinho, em 1863, afirma que a doença de pele deve estar ligada ao tipo de alimentação dos Paumari, que ele descreve como basicamente constituída pelo tecido adiposo dos peixes (principalmente pirarara) e tartarugas assim como pelo "caxiri do pirarucú" (bebida de peixe fermentado) (Silva Coutinho 1863:70). Ele também afirma que, na província, a gordura da pirarara era administrada aos papagaios, tendo a "propriedade de fazer mudar a côr das pennas, e assim consegue-se embellezar o pássaro". O autor sugere, então, sem afirmá-lo porém, que a gordura do peixe teria um efeito semelhante na pele dos Paumari ${ }^{4}$. Mais adiante, ele evoca o desinteresse destes em guerrear e suas relações com os regatões:

Antigamente, erão estes perseguidos pelos Muras, logo que descião do Paraná-pixuna, levados pelos regatões. Algumas vezes também os Muras ião atacá-los em 
suas malocas, com o fim de lhes roubarem as ubás, e outros utensílios de pesca. Alguns regatões aproveitarão-se do temor dos Pammarys para fazerem melhor negocio. Dizião que os Muras vinhão batel-os, e isso bastava para que toda a maloca os acompanhasse com medo dos inimigos. [...] Naturalmente medrosos, fogem ao menor sinal de aggressão, não só dos Muras como d'outra qualquer tribu, e encontrão recursos pelos meios que dispõe para a navegação (Silva Coutinho 1863:71).

É preciso lembrar que, nessa época, a região já começava a ser sistematicamente explorada e desmantelados os modos de ocupação territorial tradicionais, em decorrência da exploração econômica crescente da borracha e da chegada em massa de mão-de-obra nos seringais (Kroemer 1985:78).

Os Paumari contam que, antigamente, antes da chegada dos Jara (regionais) e mais especificamente dos kariva (patrões), viviam como as gaivotas (tihi) que se instalam no início do verão amazônico nas praias do Purus. Eram, portanto, muito mais numerosos do que hoje, e nessa época do ano ocupavam as praias que iam do Tapauá (rio abaixo) ao Sepatini (rio acima), mas desse modo ficavam expostos aos ataques de outros índios, os Joima, como veremos mais adiante. Depois do aparecimento da figura do kariva (patrão) e do Jara (regional), os Paumari deixaram de freqüentar as praias, demasiadamente expostas, e entraram na floresta ocupando de preferência a terra firme, mas sempre à proximidade dos lagos e igarapés, onde circulavam sazonalmente entre várias moradias ${ }^{5}$.

No tempo da borracha e até a chegada da missão, os Paumari podiam trabalhar sazonalmente para um ou outro patrão (seringalistas mas também madeireiros), transformando-se assim em seus empregados (honai abono) ou preferindo tornar-se seus fregueses (pamoari). Como fregueses costumavam endividar-se com vários patrões (fossem eles seringalistas, comerciantes ou regatões) para obter uma só coisa e ficavam, assim, inseridos numa complexa rede de relações de endividamento. Essa situação se vê confirmada pela observação de Kroemer:

Até hoje, os ciganos do Purus são considerados imundos e preguiçosos. Quando sua mentalidade lhes sugere abandonar uma empreitada, desistem, indo mariscar ou contratar outros trabalhos. Assumem muitos compromissos com vários patrões, de sorte que a dependência econômica se torna mais leve. Devem tudo a todo mundo, porém a cada um somente um pouco: uma madeira, uma tartaruga, um couro de onça, um paneiro de sorva etc. (Kroemer 1985:136).

Assim, um chefe de família trabalhava durante alguns meses para um patrão, mas ainda devia a outros que pagava com "sua produção" (kidi 
produção) ${ }^{6}$. Conseguiam assim roupas, instrumentos de trabalho (terçados, munições, armas, anzóis, linha) e alimentos como sal, açúcar, café, farinha de mandioca, em troca principalmente de peixe salgado (pirarucu), quelônios ou madeira e, mais esporadicamente, de produtos extrativos como castanha, andiroba, copaíba ou alguma extração própria de seringa ${ }^{7}$ ou sorva $^{8}$. Pode-se dizer que os Paumari eram, antes de mais nada, fornecedores de peixes e quelônios do mercado regional.

Já os meninos e rapazes, antes de se casar, costumavam sair da aldeia para trabalhar como empregados em alguma colocação (seringueiro ou madeireiro) ou em um barco, com um regatão, durante vários anos. Tratava-se, provavelmente, de uma prática nem sempre voluntária, mas os Paumari a descrevem, hoje, como tal. Ainda hoje, alguns jovens se empregam em barcos pesqueiros e só voltam vários anos mais tarde, para se casar ${ }^{9}$. Esse hábito, segundo o que contam os homens, permitia que o rapaz aprendesse o "jeito do Jara" (jara ka-hojai), "se criando com ele" e que passasse a ter um acesso regular às mercadorias (inisika) dos Brancos. O "jeito do Jara" é a maneira como estes trabalham, cortam seringa, madeira, plantam, caçam, mas sobretudo falam (português), negociam, comem, bebem e dançam. A relação assim estabelecida entre o jovem e seu empregador era duradoura e corresponderia, em muitos aspectos, a uma forma de adoção ${ }^{10}$.

Geralmente, o rapaz voltava à aldeia para se casar sem ter conseguido saldar sua dívida, mas com acesso privilegiado às mercadorias daquele patrão, por ter convivido com ele e se transformado em seu filho de criação ou afilhado. Vários homens, de todas as idades, contam hoje como puderam, assim, familiarizar-se com a comida e os hábitos dos Jara, como aprenderam a conduzir um barco e assim viajaram pelo Purus afora, conhecendo outras cidades amazônicas, outros povos etc. Assim explicam, também, como adquiriram seus sobrenomes jara e como foram criados com tal ou tal patrão, hoje na cidade ${ }^{11 .}$

Até o final dos anos 1960, os patrões da região impediam os Paumari de plantar (mesmo nas praias), de adquirir bens dos regatões, e de pescar nas águas que consideravam sua propriedade (a não ser que fosse para saldar suas dívidas). Com a decadência do mercado da borracha, a chegada da Missão e da Funai e a progressiva legalização das terras, o sistema repressivo do cativeiro foi extinto mas, ainda hoje, os Paumari costumam endividar-se com os patrõezinhos da beira do rio (ver nota 12) para conseguir os produtos de primeira necessidade ou, eventualmente, farinha e alimentos industrializados. Para isso, pagam com sua própria produção ou prestam algum serviço ao patrão: por exemplo, limpando seu terreiro ou consertando o telhado de sua casa; as mulheres lavando sua roupa etc. 
Seria interessante notar que os Paumari raramente evocam os velhos tempos da submissão aos patrões com desgosto ou revolta, pelo contrário, geralmente manifestam uma clara nostalgia daquela época, lembrando-se dela como de uma era de abundância e paz.

Assim, a 'era' dos patrões é lembrada como o tempo da fartura de mercadorias e não pode sequer ser comparada com a atual 'era' das Missões (que em larga medida ocuparam a função de provedores de bens, até então cumprida pelos patrões). É claro que essa nostalgia é relativa, e os mais velhos se lembram das violências, castigos e ameaças sofridos na época. Mas seria interessante notar que, hoje, não é disso que se lembram, mas sim do que era bom, do bom patrão generoso que aviava sem limite, mas também cuidava dos Paumari "como de seus próprios filhos", compartilhando com eles sua comida, quando vinham comerciar, dando-lhes roupas usadas e algum antitérmico quando estavam com febre. Assim, além de mercadorias, recebiam proteção e também bens simbólicos como nomes ou sobrenomes, estabelecendo laços de parentesco fictícios (visairi).

\section{Comercializando relações}

Vejamos mais de perto os diferentes termos em jogo na relação comercial.

Pamoari é o termo usado pelos Paumari como autodenominação. Por um lado, tem o sentido geral de coletivo paumari, por outro lado, o sentido contextual de freguês, quando remete à relação comercial patrão/freguês. É provável que a denominação pamoari tenha se tornado um sinônimo de freguês, por causa da inserção destes índios no sistema comercial regional. Mas há um outro termo constitutivo da relação comercial: a posição de empregado (honai abono). Apesar de pamoari significar freguês e designar os Paumari como um todo, os Paumari dão muito mais importância ao termo de empregado. Trata-se do termo que é privilegiado e que se encontra em vários contextos da sociocosmologia paumari.

O freguês (pamoari) é aquele que, endividado com um patrão, tem de produzir, extrair algo para saldar sua dívida. O que o vincula ao patrão é a dívida. Já o empregado (honai abono), encontra-se de certa forma um passo à frente no comprometimento com o patrão, e reciprocamente. Eles também estão ligados pela dívida, mas esta vai ser saldada por um serviço prestado ao patrão (que pode finalmente se traduzir numa produção). O empregado coloca-se à disposição do empregador para saldar sua dívida, e isso implica em certos cuidados por parte deste último. O termo paumari para designar o empregado traduz isso: honai abono significa "empregado", isto é, "aquele 
(alma-corpo) que está a serviço de", "aquele que trabalha por ordem de" (honari: ordem, encomenda) ${ }^{12}$.

O termo pamoari, que designa o freguês, é usado unicamente no contexto comercial, para fazer referência a qualquer freguês, seja ele Paumari ou não. Trata-se, portanto, de um termo que designa a posição primeira na relação comercial. Mas é importante ressaltar que é a relação entre o patrão (kariva) e o empregado (honai abono) que interessa aos Paumari. É de se notar que a relação patrão/empregado encontra-se tanto na cosmologia, como nos ritos e nos relatos míticos.

Assim, durante o ritual ihinika, os espíritos dos alimentos convidados à festa vêm precedidos por seus empregados-espíritos que anunciam a chegada de seus patrões ${ }^{13}$. Por exemplo, no ihinika do peixe-boi (boma), o pássaro vira$k a^{\prime} d a$ (não identificado), que do ponto de vista do peixe-boi é sua cozinheira, anuncia sua chegada aos participantes:

'Vamos primeiro pra festa porque depois tenho que passar o café do patrão'.

E o pássaro kamokia (não-identificado) que cuida do roçado do peixeboi chega anunciando:

'Prima, prima, vamos para a festa que o patrão já está lá'. Sua prima responde: 'Sim, vamos, porque ainda temos que plantar a roça do patrão'.

O carrapato (kajapa) anuncia a chegada de seu patrão, o espírito da anta ('daama), e assim por diante (parasitas são, em geral, descritos como fregueses). As relações entre patrões e empregados são encontradas também nas relações entre espíritos-alimentos de um modo geral.

Esse mesmo espírito-alimento do peixe-boi é, segundo seu ponto de vista, um patrão, branco e gordo, que navega em seu rio (debaixo do Purus) e é assistido por seus empregados: o boto tucuxi (vaikajaro), por exemplo, é seu timoneiro. Os espíritos-alimentos freqüentam os rituais ihinika na medida em que são solicitados e chamados pelos xamãs, mas é preciso notar que essa mesma relação é também encontrada em muitos outros aspectos do cosmos paumari.

Assim, os xamãs (arabani) saem à procura da alma-corpo (abonoi) da criança, quando ela é capturada por um espírito-alimento, por exemplo ${ }^{14}$. Essa captura da alma-corpo (abonoi) provoca o adoecimento imediato da criança. O xamã deve, então, (com a ajuda das cantoras e após a tomada de alucinógenos) sair a sua procura para negociá-la e recuperá-la. Enquanto isso, o abonoi da criança terá sido transformado em empregado do espírito-alimento que o capturou. Se a negociação fracassar, a captura 
poderá ser definitiva e a criança permanecerá para sempre ao lado de seu novo patrão espírito-alimento (o que se traduzirá na morte da criança).

Após a morte, o abonoi da pessoa desprende-se de seu invólucro corporal (toba bo'da) e segue caminho para o Lago dos mortos (ou para a casa de Deus (Deus gorana), no caso dos evangélicos). O Lago dos mortos (aja'di ka-'dako, o Lago da Renovação) situa-se rio acima, a meio caminho entre as cabeceiras do Purus e o rio de cima (que corre na parte celeste da rede fluvial cosmológica). Lá no Lago, vivem os mortos paumari ressuscitados após um banho mágico (e após a retirada dos resíduos alimentares acumulados ao longo da vida de seus abonoi). Após receberem um invólucro novo (toba ja'dini), os mortos são chamados para escolher entre dois tipos de móveis de repouso: a esteira (jorai) ou a cadeira de balanço.

Escolhendo a esteira, o morto permanece no lago onde leva uma vida imortal ao longo da qual poderá comer e dançar incansavelmente. Escolhendo a cadeira de balanço (aqui, símbolo do patrão amazônico), ele será então imediatamente empregado pelo patrão-chuva (forma humana da chuva: bahi ka-pamoarihi), espírito meteorológico que, como o sol, é descrito como um patrão muito poderoso, ou seja, rico e generoso, o que se traduz na sua aparência forte, corpulenta e no seu caráter colérico, mas também na quantidade de barcos que possui (uma frota inteira), todos dirigidos por seus empregados mortos paumari que vão buscar água nos reservatórios de Manaus (no extremo leste do espaço cosmológico), navegando pelo rio de cima, para derramá-la sobre as terras paumari. São esses empregados do patrão-chuva que também asseguram, através do trovão, a comunicação regular entre os xamãs paumari e os mortos ${ }^{15}$.

Interrogados sobre o interesse de estar trabalhando para um patrão até depois de mortos, os Paumari respondem, unânimes, que o patrão-chuva (bahi ka-pamoarihi) é não somente poderoso, mas também bom, generoso e que possui quantidades ilimitadas e muito variadas de mercadorias (inisika).

Há, portanto, algo aí que a posição de freguês não garante: a regularidade do acesso aos bens e o comprometimento do patrão para com seus empregados. O patrão garante a seus empregados o acesso a bens, alimentação e cuidados (inclusive através da nomeação, do apadrinhamento, da administração de remédios), em troca de serviço e produção. 'Estar servindo alguém' é então estar sob sua proteção e ser alimentado direta ou indiretamente por ele. Isso nos faz pensar imediatamente na questão da comensalidade amazônica e da familiarização de animais e pessoas (Fausto 2002, Vilaça 2002). Aliás, os filhos adotivos são muitas vezes descritos pelos Paumari como honai abono, empregados, de seus pais. Essas mesmas crianças são tidas como uma "criação"16. Assim, a expressão em português "minha 
criação" designa tanto os filhos adotivos, como os animais de estimação. O tema da familiarização parece ser levado aqui ao nível sociocosmológico, mas ele é apreendido do ponto de vista da presa, do objeto da familiarização, e não do ponto de vista do predador ou do domesticador.

É como se a dinâmica da sujeição, imposta historicamente na região, tivesse sido digerida e invertida no sistema relacional paumari. Talvez o privilégio dado à posição de empregado possa ficar mais clara, se pensarmos agora na outra observação que mencionei acima: a da definição de si mesmos como presas.

\section{O pamoarihi}

O termo pamoari (ou paumari) é usado como autodenominação. Os Paumari não usam o pronome pessoal na primeira pessoa do plural, nem um termo significando "humano" ou "gente" para se autodesignar ${ }^{17}$. O termo pamoari tampouco parece ser uma denominação dada por algum grupo vizinho, como é comum na Amazônia. É, portanto, desse modo que os Paumari distinguem-se de outras nações, como os Jara (regionais), os Viporina (Apurinã), os Jamamadi e outros Joima (índios selvagens), assim como dos Americanos (estrangeiros de pele e olhos claros). Às vezes, é pelo termo 'paumari' que os regionais mais próximos se referem a eles, para distinguilos da categoria genérica 'caboclos', usada para designar os índios em geral, por definição tidos como 'brabos'. Os Paumari, quando assim chamados pelos regionais, são considerados os índios 'mansos' por excelência, que foram 'amansados' e que aprenderam rapidamente os modos 'civilizados' (qualidade que é invariavelmente associada, ao menos nessa parte do Purus, à possibilidade de se comerciar com eles). O único perigo que os Paumari representam para os Brancos é o de provocar doenças de pele: seus xamãs podem agredi-los, enviando feitiços sob a forma de um pó que provoca doenças de pele, como impingem ou pinta, por exemplo.

Como já vimos, o termo pamoari recobre dois sentidos específicos, não exclusivos: o primeiro, que acabamos de ver, é o de Paumari enquanto coletivo. O segundo, como já vimos, é o de freguês, no contexto da relação comercial. Mas ele também é usado para formar uma expressão que indica a qualidade potencial de humanidade, algo assim como a 'pamoaritude' ou 'pamoaridade' de um ser ou de um objeto. A expressão formada por um substantivo, seguido da autodenominação pamoari, precedida pelo prefixo possessivo $k a$ - e seguida da partícula - $h i$, indica a forma ou a qualidade humana do substantivo que precede. Assim, todos os animais, vegetais e objetos inanimados podem ser percebidos sob sua forma/qualidade 
humana, social. Assim, o boto é potencialmente humano e social, pois pode aparecer sob forma humana e vive, nos rios e lagos do Purus, em sua aldeia com seu povo; faz suas festas; fala sua língua; se casa e tem filhos.

Quando alguém se refere ao boto, usa o termo 'basori'. Entretanto, quando se trata de falar de seus congêneres, de sua vida em sociedade ou de seus hábitos de vida (antes de sua captura), de sua 'pamoaritude', fala-se, então, de 'basori kapamoarihi, referindo-se, desse modo, à sua vida social e ao coletivo dos botos. Neste contexto, os Paumari traduzem a expressão como "povo do boto" ou "nação do boto". Trata-se de uma condição social comum a todos os seres, animados ou não, e que se materializa, aos olhos dos Paumari, pela transformação destes seres em humanos. Assim, um caçador que encontra na mata um ser estranho com aparência humana pode ter visto, de fato, o pamoarihi de algum animal silvestre, ou seja, algum animal silvestre sob sua forma humana.

Reencontramos aqui, sem dúvida alguma, o tema clássico do perspectivismo amazônico (Viveiros de Castro 1996), como que projetado no conjuntos dos seres e objetos que povoam o mundo. É interessante pensar o perspectivismo generalizado dos Paumari em relação à questão dos subgrupos arauá (que também foram chamados de clãs), pois aqui, a socialidade potencial é projetada na totalidade do cosmos e coincide, ao menos lingüisticamente, com o que foi chamado de subgrupos madiha (conforme o modelo e o termo kulina). Os Paumari não apresentam hoje em dia configurações sociológicas do tipo madiha. Os subgrupos localizados, nomeados e idealmente endógamos não existem enquanto tais. Os grupos locais são unidades idealmente endógamas, mas não são associadas a nomes de animais ou plantas e são conhecidas por seus nomes próprios. Assim, os habitantes do grupo local do Crispim são chamados de Crispim kapamoarini, assim como os do Marahã como um todo são Maraha kapamoarini (vários grupos locais, todos situados à proximidade do Lago Marahã). Aqui é como se a configuração madiha tivesse sido projetada no cosmos incluindo, então, as relações entre os Paumari como um todo e todos os outros seres potencialmente sociais. Os 'subgrupos' coincidem, então, com as espécies ou subespécies vegetais e animais, ou mesmo com os objetos, com os quais os Paumari têm de se relacionar no cotidiano. Essa idéia vê-se confirmada por uma série de relatos que narram casamentos frustrados ou malsucedidos entre Paumari e pamoarihi de diversos animais e nos quais são expostas as normas e formas ideais do casamento que coincidem com o que foi descrito para os madiha kulina (no que diz respeito à residência, à procriação, às regras de pertencimento ao subgrupo e às relações com os afins) (Pollock 1985). 
Mas voltemos à noção de pamoarihi de todos os seres. Ela é fundamental para a compreensão da concepção paumari das relações entre predadores e presas. Dissemos que a segunda constatação sobre a qual se baseia este ensaio etnográfico é a de que os Paumari se descrevem e se concebem invariavelmente como presas. Vejamos então como estes concebem as relações entre presas e predadores.

\section{Igitha e tapo'ija}

Os animais, de modo geral, são classificados pelos Paumari segundo duas posições: a de presa ou a de predador, igitha ou tapo'ija. Em Paumari, o termo igitha designa a presa, por oposição ao termo tapo'ija, predador. Dependendo da situação, todos os seres podem ser categorizados em uma ou outra dessas posições, seguindo a fórmula amazônica recorrente. Entretanto, alguns animais são quase que sistematicamente classificados como igitha; é o caso da maioria dos animais considerados inofensivos, como os pássaros, principalmente, mas também os quelônios e animais muito pequenos (excetuando os insetos e animais peçonhentos que são considerados predadores ${ }^{18}$ ). Da mesma maneira, alguns predadores serão invariavelmente tapo'ija, como a onça (jomahi) ou a sucuri (mabidiri), predadores por excelência. O termo igitha é usado também para nomear os animais domésticos e é usado, por extensão, no cotidiano, para designar os pássaros de um modo geral (o termo completo sendo igitha raboki).

O socius paumari é constituído por coletivos potencialmente humanos, sejam eles animais, plantas ou objetos. Todos possuem, individualmente, a capacidade potencial de adotar uma forma humana, e, coletivamente, todos os seres e objetos são potencialmente sociais. Assim, quando digo ojoro kapamoarihi posso estar me referindo a um jabuti que adota a forma ou a aparência humana (em um mito ou em um encontro sobrenatural na floresta, por exemplo), ou ao coletivo jabuti, que vive no mato, em suas aldeias; que tem suas casas; planta seus roçados e faz seus rituais ${ }^{19}$.

Ora, quando um pescador paumari mata um pirarucu (baba'di), não é o abonoi (alma-corpo) dele que é atingido. O que ele, pescador, vê como pirarucu é apenas uma esteira (jorai) que o pamoarihi do pirarucu lhe entrega ou troca por munição ou flechas (aquelas usadas pelo pescador). Assim, todo ato predatório é concebido como uma troca (ou um dom) entre um caçador ou pescador paumari e o pamoarihi (forma humana/ social) da presa (igitha). Mas o que os pamoarihi das presas trocam ou dão, são sempre seus objetos culturais ou mercadorias. Dessa forma, a piranha e o jundiá dão um 
anzol; o peixe-cachorro dá uma faca; o peixe jaú dá uma roupa; o peixe-boi, um bote; o jabuti, um kajamari (antigo cocar paumari); a anta dá uma rede ao caçador; a queixada, dá uma panela com comida; os pássaros, em geral, dão suas penas que, de seu ponto de vista de pássaros, são seus remos ou suas facas.

Os Paumari afirmam que quando consomem um alimento, "ni-ahaiki abononi", ou seja, "não se come a sua alma-corpo", mas trocam-se ou recebemse objetos. Assim, no contexto predatório, as presas, e até certo ponto também os fregueses paumari, trocam sua produção (objetos culturais ou alimentos) por bens manufaturados (chumbo, anzol, linha, rede, arpão). Alguns informantes afirmam, no entanto, que a predação consiste no dom de um alimento ou objeto do pamoarihi das presas para seus predadores, sem evocar nenhum tipo de reciprocidade. Este é sem dúvida um problema que terá de ser aprofundado posteriormente, mas, neste caso, cabe perguntar se esta dupla relação não remeteria à dupla posição freguês/empregado (pamoarihi/ honai abonoi) em sua relação com a posição única de patrão (kariva) ${ }^{20}$.

De certa forma, a predação é aqui apreendida, seja através da troca, seja através do dom, do ponto de vista da comercialização das relações que evocamos anteriormente. Providos de seu próprio ponto de vista, os igitha (presas) se posicionariam no seio da relação predadora, assim como os Paumari se posicionam ao relacionarem-se, hoje, com Outros, isto é, como fregueses ou empregados. Ora, não creio que se trate, aqui, apenas de um modo de evitar ou contornar a predação (e muito menos de compensá-la), e sim de um modo mais profundo de vivê-la, de atualizá-la realmente ${ }^{21}$. Isso fica mais claro quando analisamos mais de perto a outra observação etnográfica que mencionei no início do ensaio. Vejamos quando e como os Paumari encontram-se na posição de presa, ou seja, quando são caçados, mortos ou se sentem ameaçados por outros.

\section{A condição de presa}

É fundamental assinalar aqui que, em muitos contextos, os Paumari descrevem a si mesmos como presas e costumam dizer que, antigamente, eram como igitha, ou seja, presas dos índios selvagens (Joima) ou animais domésticos (cujo animal prototípico é o pássaro) de tal ou qual patrão. Seguindo a lógica perspectivista, os índios selvagens, os Joima, vêem os Paumari como queixadas (hirari), e é por isso que, antigamente, costumavam caçá-los para devorá-los. Quando se trata de descrever os ataques de índios vorazes, vindos de longe para apreciar a sua carne, os Paumari usam metáforas e comparações para descrever suas reações, com detalhes que lembram àquelas dos pássaros inofensivos, fugindo de seu predador (es- 
condem-se no oco de um pau, no topo de uma árvore, em um buraco de tatu, fogem para o mato etc.). Só os seus xamãs (arabani) e os antigos Jobiri conseguiam livrá-los da voracidade alheia ${ }^{22}$ : os xamãs, graças a seus cantos e seus poderes transformacionais; os Jobiri, graças a seu treinamento físico, a sua agilidade, sua destreza e sua capacidade de se camuflar. Estes últimos esquivavam as flechas dos Joima para recuperá-las e lançá-las de volta contra eles. É o que conta este curto relato:

Os Paumari gostavam de ir atrás de fruta (ihi'ai) na terra firme, iam para a mata e levavam os filhos. No São Francisco, lá pra cima, onde tem muita castanha, bem baixo, na beira do rio, tem um morro. Nesse tempo, os Jobiri atacaram os Joima que nos atacavam. Foi o derradeiro ataque. Foi só um Jobiri que venceu todos os Joima. Tinha só uma criança (isai). Ela se enfergou com o lodo dos paus e entrou num buraco de tatu canasta, entrou e colocou capemba de jari. Ela ouviu os Joima acabando com todos os Pamoari. Aí, a criança (isai) correu, correu enquanto os Joima já estavam fazendo o moquém (basika) dos Pamoari. As tripas (bakaijona) dos Pamoari eles jogavam no igarapé. Essa criança era treinada para ser Jobiri. Aquele lugar se chama I'dokoa (poço bem grande), ele era respeitado porque parece uma panela cozinhando, borbulhando. Não era para ele pular, ele saltou dentro da água e ele nadou e foi boiar bem perto da canoa do avô. Aí ele se salvou. O avô venceu todos eles, porque ele evitava as flechas e usava-as contra os Joima (F, 20/8/2001, Crispim, em paumari e em português).

Seria interessante notar que, nesses relatos, os Paumari aparecem sempre como o alvo dos ataques e não podem nunca revidar as agressões diretamente. Eles são sempre defendidos ou vingados por outros, semelhantes (mas não iguais), isto é, Jobiri ou xamãs. Assim, os Jobiri são geralmente apresentados como um exército defensivo ('akadisorara, nossos soldados). Em dois outros relatos, outras figuras aparecem como seus defensores. Em um relato que me foi contado em Paumari é um casal de crianças paumari, criado pelos Joima, que livra os Paumari de seus parentes adotivos, agressores. Outro relato conta como um menino apurina ${ }^{23}$, criado pelos Paumari, os salva de uma matança, solicitando a ajuda de seus valentes parentes apurinã:

Dizem que uma nação que ficava perto dos Paumari cortava as cabeças dos inimigos para fazer flautas. Agora, mais recentemente, os Viporina defenderam os Paumari quando os Joima os atacaram. Um arabani pamoari colocou o barijaro [mistura com osso de peixe para botar na boca da criança depois da festa para ela poder comer ${ }^{24}$ ] numa criança viporina. Quando ele estava com uns 12 anos, ele quis ficar com o padrinho dele pamoari [...]. Ele falava nas duas 
línguas. Aí, os Pamoari mariscavam ali no Lago Branco [área do Marahã25]. Cada dia, sumia gente, cada vez que ele ia mariscar. Aí, ele falou para o pai de criação dele que ele ia ver isso com o irmão de criação. Mas ele não andava na popa da canoa, ele subiu numa árvore na boca do igarapé. Aí, ele ficou lá só olhando para os mariscadores paumari. Quando chegava um no meio do lago, chegava a canoa dos Joima, coberta com palha. Quando um mariscador matava um baba'di (pirarucu), o Joima matava o mariscador. Então o menino falou: "agora eu vou valer os Pamoari contra esses Joima". Ele passou o dia rapando ava (pau, entrecasca) e se untou o corpo com o lodo do ava. Aí, ele se bronzeou com lodo para poder acompanhar esse Joima, aí ele chegou na maloca do Joima e viu eles comendo o irmão de criação dele moqueado ${ }^{26}$. Aí ele chegou lá (camuflado com o lodo) e falou. A moça (joima) disse assim: "Você quer comer?" Ele aceitou. Ele recebeu carne do irmão dele, mas ele não quis, só aceitava baba'di e carne de caça. Aí, ele passou a noite dançando com os Joima. Aí na roda, ele entrou em três, quando foi na quarta vez da roda girar, ele saiu para o rumo da boca do caminho que era bem largo e limpo e ele pegou a canoa ${ }^{27}$. Os Paumari moravam na praia do Maraha.

Quando ele chegou lá, ele disse para o pai que sabia o que era que estava acabando com a nação paumari, ele falou que ia avisar a nação dele para acabar com os Joima valentes [do Lago do Gil]. Aí, ele foi nos Viporina e disse: façam uma grande comida para não faltar peixe para esse pessoal. Aí, os Apurinã convidaram os Joima e mataram todos eles e comeram só a barriga deles [eles comem só onde tem a banha na barriga] e voltaram lá para o Sepatini. Isso aconteceu ainda quando eu era pequena [...] (F.,Crispim, 22/8/2001).

Assim, crianças adotivas são intermediárias entre os Paumari e seus defensores (Jobiri, Viporina ou arabani). Seres inofensivos e ainda em processo de socialização são os que permitem aos Paumari se defenderem dos vorazes Joima. Trata-se, portanto, de um pacifismo intermediado, 'terceirizado', e não de uma recusa categórica da agressão e da vingança. O meio de conhecer e de controlar a agressividade do inimigo é sendo socializado, de preferência pacificamente, por ele. O objeto ideal da socialização é a criança. Ela é socializada, domesticada através da adoção, da familiarização e da socialização (que se traduz, principalmente, pelo domínio da língua de outrem).

Os xamãs são outros grandes defensores dos Paumari. Mas eles não são descritos como soldados, como os Jobiri. O que é salientado nesses casos são seus poderes transformacionais. Eles, mais especificamente, livravam os Paumari das agressões alheias, enganando os agressores ou transformando-os em presas (igitha). Assim, conta-se que os xamãs paumari livraram uma aldeia de um cerco de Joima que se fechava em torno de um de 
seus acampamentos, rio acima, durante um ritual de puberdade. Para enganar os inimigos, os xamãs, cantando, imitaram choros de crianças na boca de um caminho, enquanto todos fugiam pelo outro lado. Quando os Brancos de Manaus vinham para capturar os Paumari e forçá-los a trabalhar, ou para exterminá-los, um xamã chamado badori Titxatxa (vovô Titxatxa) transformava-os em pássaros (em araras mais especificamente) quando seus barcos entravam nos lagos e enviava insetos que invadiam os porões dos navios e devoravam as reservas de víveres. Neste caso, a arma dos Paumari, frente aos inimigos vorazes, é o poder transformacional xamânico mas, sobretudo, a artimanha, a astúcia dos seus xamãs.

Os massacres de Paumari descritos por viajantes ressaltam freqüentemente que estes últimos eram alvo de perseguições, roubos e matanças. Assim, Silva Coutinho afirma que:

[...] houve um grande combate entre os Pammarys e os Muras. Estes sairam vencederos, tendo morto grande número de contrários; os cadáveres apodreceram na praia, e achou se ainda muito depois os ossos espalhados (Silva Coutinho 1863 apud Cunha Neiva 1975:20).

Brown e Lidstone também evocam o destino dos Puru-puru em termos trágicos :

Deve ter ocorrido uma terrível tragédia em alguma época na história desta tribo pois uma ilha - uma das poucas do rio - que vimos apropriadamente à luz de um pôr do sol vermelho como sangue tem o nome terrivelmente significativo de "ilha do massacre dos Purupurús" (Brown \& Lidstone 1878 apud Cunha Neiva 1975:21).

A violência e a vingança diretas são substituídas pela agilidade, pela astúcia e pela capacidade de sedução dos (ou pela submissão aos) predadores, através do domínio das técnicas corporais (agilidade dos Jobiri e capacidade de se camuflar em crianças) e verbais (cantos xamânicos, música, imitação de choros de crianças e bilingüismo). Isso nos lembra as técnicas várias de sedução de presas e de familiarização dos animais. Assim, para atrair um igitha é preciso observá-lo, às vezes, é preciso saber imitar seu canto (para os Paumari todos os animais têm seu próprio canto e portanto possuem capacidade de se comunicar), conhecer seus hábitos (saber onde ele bebe água ou por onde passa, que tipo de frutas come, e saber reconhecer seus rastros). A familiarização está baseada nos mesmos princípios da comensalidade amazônica, que se aplicam tanto aos animais domésticos 
quanto às crianças adotivas. É preciso, antes de mais nada, alimentar o igitha (animal doméstico), compartilhando com ele os alimentos consumidos cotidianamente, nomeando-o, protegendo-o, abrigando-o e, em alguns casos, dividindo o mesmo espaço vital com ele (casa, mosquiteiro, rede), desse modo transformando-o plenamente em parente (Vilaça 2002; Fausto 2002).

Em suma, trata-se de comportar-se como se espera que o patrão domesticador se comporte com seus empregados, devendo-lhes cuidados, dedicação e, de preferência, estabelecendo laços duradouros com estes (através da nomeação e do apadrinhamento). Do ponto de vista da presa, a alternativa é a morte, a devoração ou a domesticação (a familiarização pelos seus predadores), assim como, no contexto comercial, a alternativa para os Paumari é serem fregueses ou serem empregados. E, neste contexto, parecem claramente preferir a segunda opção.

Quando se trata de salientar seu suposto pacifismo, os Paumari comparam-se a pássaros ou presas que preferem cantar e viver entre si, a guerrear. A comparação de si mesmos com os igitha encontra-se em vários contextos relacionais e, principalmente, em contextos históricos. Por exemplo, quando se trata de descrever a partida definitiva da primeira missionária do SIL (Summer Institute of Linguistics) que trabalhou na área, os Paumari contam seu desespero comparando-se com órfãos que teriam ficado " $\mathrm{Co}$ mo patinhos sem mãe". Essas afirmações são, evidentemente, imagens, metáforas que servem, por um lado, para ressaltar a preocupação atual dos Paumari com o estabelecimento e a preservação de relações pacíficas com os Brancos e outros povos e, por outro lado, para descrever as relações de proximidade e dependência que os une uns aos outros (ideal endogâmico e comensalidade) e aos outros mais próximos (alguns patrões, regionais e estrangeiros conhecidos).

As analogias feitas entre Paumari e igitha (presas, pássaros, animais domésticos) observam-se, também, nas várias versões que colhi dos relatos que contam a chegada da primeira missionária do SIL ao Lago Marahã. Assim como os Joima vinham de longe para "apreciar a carne dos Paumari", os Americanos - estrangeiros vindos de longe —também causavam temor, pois sua fama era a de que capturavam crianças paumari para a fabricação de carne enlatada (corned-beef) — até hoje comercializada na região ${ }^{28}$. Os relatos evocam o primeiro encontro com a estrangeira, seguido da fuga dos Paumari (que esconderam seus filhos dentro de suas casas e no mato); a progressiva domesticação destes pela missionária, notadamente através do dom de presentes, da troca de bens por produções paumari (artesanato principalmente) e do tratamento da doença de pele; até sua partida definitiva e o conseqüente sentimento de abandono dos Paumari. 
Nota-se, também, que relatos que contam a perseguição incessante dos Paumari por esses estrangeiros vorazes e agressivos são muito contados durante o verão amazônico. É bem verdade que a maior parte de meu trabalho de campo foi feita nesta época, mas essa observação coincide com um fato recorrente que, como pude observar, sempre ocorre nesses meses. O verão amazônico (badara), que começa aproximadamente em maio e vai até final de outubro, é a época em que os Paumari se mudam para suas habitações de praia. Saem, portanto, das habitações de terra firme e dos flutuantes dos lagos para se instalarem nas praias e cultivar produtos que, em sua maioria, são comercializados com regatões ou na cidade (mandioca, milho, feijão, abóbora, melão e melancia, principalmente). Nestes meses, encontram-se, como no passado, expostos aos contatos com visitantes e navegantes vindos de todas as partes do Purus e da Amazônia. Nessa época, surgem rumores segundo os quais marginais vindos de Porto Velho ${ }^{29}$, ou Joima, mandados pelo governo de Porto Velho, estariam a caminho e viriam para matá-los e devorá-los. Geralmente esses rumores são veiculados quando alguma pessoa constata o sumiço de algo em sua casa; ou quando alguém relata que viu uma pessoa à noite, no escuro, roubando melancia (nessa época do ano, uma das principais diversões das crianças e, diga-se de passagem, dos adultos também).

Em 2001, os Paumari estiveram, durante uma semana inteira, muito mobilizados e preocupados, confinando as crianças em suas casas e limitando seus deslocamentos, temendo a chegada dos marginais de Porto Velho. Já em 2002, uma joima anani 'bo'da (literalmente "fêmea de índia velha"), que andava armada e nua, teria sido avistada, atravessando o rio Ituxi em uma balsa improvisada, se dirigindo, rio acima, para as aldeias paumari. Na praia, à noite, os Paumari deixaram de circular pela aldeia e se mostravam preocupados com minhas idas e vindas ${ }^{30}$. À medida que o tempo passava, os detalhes iam se afinando e, certo dia, um casal que mora rio acima, depois de indagado sobre o por que da índia ainda não ter chegado, me advertiu que o provável motivo de seu atraso seria o fato de ter parado ao longo do caminho para comer gente:

Ela é brava porque não tem roupa e ela fugiu ou então foi comprada [enviada] pelo governo de Porto Velho. Ela gosta mais de criança moqueada. Ela come o que pode e joga o resto para os urubus. Os Jara quebraram seu arco, mas ela ainda tem uma flecha e ainda pode fazer outro arco no caminho. Ela atrai as crianças com bombom [balas], biscoito, bolacha, mata elas, moqueia e come. Você viu o Zé Luis [o filho do casal] no caminho? [Respondo que não, e a mulher afirma então] Se Joima já não pegou ele! Ela só ataca uma ou duas pessoas de cada vez (K. e D., Santa Rita, 30/7/2002, tradução e parênteses meus) ${ }^{31}$. 
O detalhe de ela ter sido enviada pelo governo de Rondônia é interessante pois coincide com o que dizem os Paumari sobre os Joima que vinham matá-los no passado. De fato, estes vinham sempre do Madeira e de seus afluentes, o que coincide com a localização geográfica do perigo atual. Vários outros rumores do mesmo tipo circularam nessa época, mas estes foram os dois principais que marcaram, de fato, a vida aldeã nos verões de 2001 e 2002.

Assim, quando o perigo é a devoração, o ponto de vista privilegiado é o do igitha-animal doméstico, assim como quando o perigo é a exploração e a dominação econômica, o ponto de vista privilegiado é o do empregado. Perguntei-me, então, se trataria-se aqui unicamente de uma posição pacifista particular dos Paumari ou unicamente de uma maneira de evitar a predação. É preciso pensar nas duas posições oscilantes de presa/animal doméstico e freguês/empregado como posições alternativas que são ocupadas em um contexto relacional potencialmente perigoso. São os Paumari que oscilam entre uma e outra posição, conforme o contexto no qual se encontram. Ocupam então a posição fraca, a priori, da presa domesticável para escapar à devoração ou à exploração econômica com fraco rendimento relacional. Hoje em dia, o predador potencial não tem escolha. É transformado, pelo deslocamento dos próprios paumari, em patrão domesticador.

É a domesticação dos Paumari que permite a pacificação dos estrangeiros vistos como potencialmente perigosos e vorazes. Ou seja, a autocolocação dos Paumari em uma posição de presa domesticável obriga o estrangeiro a adotar a posição correspondente de pacificador domesticador (ou familia-rizador), o que permitiria afastar o perigo da predação e da devoração, mas também controlar a predação potencial pelos próprios Paumari. Da mesma maneira, os Paumari podem procurar fugir da condição 'precária' de freguês, colocando-se sistematicamente na posição de empregado, de forma que o patrão lhes deva os cuidados e atenções requeridos nessas circunstâncias.

Essa idéia é mais uma vez reafirmada em um outro relato que retraça - integrando fatos históricos - o primeiro contato comercial com os Brancos e a passagem do estado de guerra interétnica (com os Joima e com os Brancos) à era do comércio, das mercadorias e do clientelismo. A história conta como Orobana ${ }^{32}$, enviado pelo governo (de Manaus) para pacificar os Paumari, é previamente domesticado pelo mestre dos animais (que lhe ensina os hábitos e a língua paumari), o que lhe permite aproximar-se dos Paumari sem, por sua vez, ser transformado em igitha ${ }^{33}$ e como, a partir de então, a situação se inverte, e ele se torna um patrão domesticador, provedor de bens e protetor de seus empregados ${ }^{34}$. A partir do episódio de Orobana, inicia-se a nova era do comércio e da paz. 
À primeira vista, poderíamos pensar que o patrão passaria a ocupar simplesmente a posição do inimigo, a do predador estrangeiro. Mas o papel do patrão nos contextos valorizados pelos Paumari não é o de inimigo, e sim, o de domesticador. Ele é, portanto, compreendido do ponto de vista da presa familiarizável paumari (freguês) ou do animal doméstico (empregado). O patrão ocupa uma posição de autoridade e dominação à qual tem de submeter seus fregueses e empregados, mesmo que seja pela força, mas sua agressividade potencial e o perigo que ele representa (o patrão-sol, por exemplo, é vermelho como os Americanos ${ }^{35}$ ) são controlados pelos Paumari, que se deslocam da posição de presa/freguês para a posição de animal doméstico/empregado, impondo assim as condições de realização da relação em seus próprios termos. Assim, levando essas idéias às suas últimas conseqüências, a arma predatória dos Paumari seria sua capacidade de submissão, submissão esta que obrigaria qualquer interlocutor em posição de dominação a apiedar-se deles e a adotá-los, como se fossem, de fato, "patinhos sem mãe". Haveria nessa capacidade de neutralização do perigo predatório uma potência e uma força excepcional, um poder de controle que talvez, neste trabalho, eu ainda não tenha conseguido descrever ou explicar de maneira adequada.

Esse controle exercido pelos Paumari quando insistem em submeter-se lembra, em muitos aspectos, a análise deleuziana do sadismo e do masoquismo (e terá de ser pensado posteriormente em relação a ela). De fato, Deleuze mostra como, no caso do masoquista, a submissão à lei e ao castigo, subvertendo e denegando humoristicamente a lei em si e a culpabilidade, permite que o seu objetivo (o prazer) seja atingido (Deleuze 1967:77-79, 105-115).

Creio que essa teoria paumari do clientelismo e do controle do outro através de sua pacificação representaria, sem dúvida, uma transformação do tema da familiarização na Amazônia. A transformação do predador/inimigo em patrão/domesticador se faz através do reposicionamento dos próprios Paumari, que se deslocam literalmente da posição de presa/freguês para a posição de ser domesticável/empregado. Assim, preferindo a submissão à devoração, eles talvez controlem o perigo da predação.

Recebido em 10 de dezembro de 2004

Aprovado em 15 de abril de 2005

Oiara Bonilla é doutoranda no Laboratoire d'Anthropologie Sociale da École des Hautes Études en Sciences Sociales, Paris. Email: <oiarabonilla@hotmail.com> 


\section{Notas}

* Este ensaio é uma versão corrigida e ampliada de uma reflexão em curso que foi apresentada em junho de 2004, na 24a Reunião da ABA (Fórum de pesquisa: Transformações Indígenas: modos e regimes de alteração e segmentação), em Olinda e na reunião do NuTi - Pronex (25/06/2004), no Museu Nacional (UFRJ). Os dados e as idéias aqui expostos tinham sido apresentados em 2003 no Seminário Americanista e no curso de Philippe Descola (EHESS, Paris). Agradeço a AnneChristine Taylor, Tânia Stolze Lima, Eduardo Viveiros de Castro, Philippe Descola, Philippe Erikson e Márnio Teixeira Pinto pela oportunidade que me deram de apresentar este primeiro trabalho sobre os Paumari e pelas observações e sugestões que me fizeram. Agradeço a Shirley Chapman e Meinke Salzer pelos relatos que me fizeram sobre o tempo que passaram na área e os inúmeros esclarecimentos que me forneceram sobre a gramática paumari. Os erros eventuais são de minha inteira responsabilidade.

${ }^{1} \mathrm{O}$ termo ariathi designa a língua paumari do ponto de vista do falante, o termo pamoari athini sendo usado do ponto de vista do não-falante ou do aprendiz da língua e contrapondo-se ao jara athini (a língua portuguesa). Quando um termo é usado pelos Paumari nas duas línguas (paumari e português) procurei apresentar os dois termos (em "português" e em pamoari). Os termos usados habitualmente em português aparecem grifados como se fossem palavras paumari (paumari, americano).

2 Shirley Chapman, da Sociedade Internacional de Lingüística, chegou ao Marahã em 1964 e trabalhou trinta anos na área.

${ }^{3}$ Treponema carateum. Treponematose endêmica (sífilis não-venérea) que causa modificações na cor em algumas zonas da pele, podendo sugerir uma forma de pintura. A doença foi erradicada pelas missionárias do SIL com administrações de penicilina. Essa afecção parece cumprir o papel de marca identitária (tatuagem ou pintura corporal) para os Paumari, e sua origem é contada em um mito sobre o qual não caberia falar aqui.

${ }^{4}$ Hoje, os Paumari e alguns regionais também evocam a ingestão de banha de peixe, de pirarucu, principalmente, como causa da doença de pele.

${ }^{5}$ Até a chegada da missão evangélica em 1964 (SIL) na área e a posterior fixação (relativa) da população paumari em aldeias, os Paumari circulavam constantemente entre os lagos de diversos afluentes dos Purus: Sepatini, Ituxi, Tapauá. Isso 
provavelmente permitia que escapassem do controle dos patrões sobre suas vidas e atividades (inclusive comerciais com diversos patrões e regatões).

${ }^{6}$ Produção aqui é o termo usado em português pelos Paumari e designa todo produto extraído do meio ambiente (e não produzido, no sentido de fabricado). Hoje em dia, o artesanato é produzido para venda e trocado por dinheiro e mercadorias, mas cada tipo de objeto é designado pelo termo específico que descreve seu processo de fabricação. Assim, uma mulher pode se referir a seus balaios como kodivaraja (meus balaios) ou kodirabahi (o que eu teci).

${ }^{7}$ Designação da goma-elástica de várias espécies de Hevea (Aurélio eletrônico 2000).

${ }^{8}$ Fruto da sorveira. Árvore apocinácea (Couma guianensis), da floresta úmida, que se caracteriza pelos frutos bacâceos, comestíveis e cujo látex é amargo, não servindo para beber (Aurélio eletrônico 2000).

${ }^{9}$ Hoje, outros tipos de afastamentos apareceram. Trata-se dos cursos de professores e de enfermagem que são periodicamente organizados em Lábrea, em outras aldeias ou em outras cidades da região. O aluno sai da aldeia por períodos mais curtos, mas repete a experiência por vários anos, podendo conviver com os Jara e com os Joima, sem deixar de aprender "o jeito dos Jara". Se ele não tem tempo de estabelecer relações duradouras com Brancos nessas ocasiões, em compensação, passa a ganhar uma posição profissional (reconhecida pelos Brancos) e, sobretudo, um salário, ou seja, outra forma de ganhar acesso a bens de consumo. Por outro lado, creio que os cursos bíblicos organizados todos os anos pela missão evangélica, em Porto Velho, também têm de ser analisados nesta perspectiva, levando em consideração que eles dão a possibilidade a casais de saírem da aldeia, pois não tenho conhecimento de solteiros que participem desse tipo de curso (com excessão de um rapaz que foi enviado pelas missionárias do SIL para estudar por vários anos em um colégio evangélico no Mato Grosso e que hoje já regressou à aldeia).

${ }^{10}$ Assim, muitos afirmam hoje: "eu me criei com jara" (eu cresci e vivi com eles). É o que dizem, inclusive, alguns patrõezinhos atuais (mesmo que em um sentido um pouco diferente) quando querem diferenciar-se de seus antigos patrões e de sua cruel reputação: "nós nos criamos com os caboclos, hoje somos compadres".

11 Os principais patrões para os quais os Paumari trabalhavam se instalaram em Lábrea ou em outras cidades amazônicas onde são hoje donos de lojas, hotéis 
e postos de gasolina. Muitos fregueses (regionais) desses patrões ficaram na beira do rio e são os chamados "patrõezinhos", outros tornaram-se regatões.

12 Professor é ojomo'ihi abono (alma-corpo que ensina); pescador: araba abono etc. O termo abonoi designa o tronco (do corpo), o corpo como um todo e a alma-corpo (princípio anímico associado à corporalidade, espírito, ou "corpo animado").

${ }^{13} \mathrm{O}$ ritual ihinika consiste principalmente na introdução (pelo xamã) no abonoi (alma-corpo) da criança dos abonoi de todos os alimentos que ela pode vir a ingerir ao longo da vida.

${ }^{14}$ Isso acontece geralmente (mas não unicamente) quando os pais não respeitam as prescrições (kaaji) a serem seguidas após a realização do ihinika (não bater na criança, não deixá-la machucar-se nem assustar-se, não deixá-la cair etc.).

${ }^{15}$ Esse parece ser o destino póstumo predileto dos xamãs.

${ }^{16}$ Em Paumari, kodinavijava designa "minha/meu (filha/o de) criação" (adoção) e kodigitha, "meu animal de estimação" (familiarização). Note-se que a língua portuguesa permite essa ambigüidade entre "ser criado por alguém" e "ser criado de alguém".

${ }^{17}$ O termo ija'ari significa "gente", "pessoas" e não é usado como autodenominação, nem com valor de primeira pessoa do plural, como em português: "a gente".

${ }^{18}$ As palavras fera e inseto, em português, são usadas como sinônimos de tapo'ija.

${ }^{19}$ A mesma formação gramatical pode indicar o material do qual é feita alguma coisa e, por extensão, sua qualidade, sua aparência. Assim, ja'di kagorahi, é uma casa feita de pedra (Chapman, S. e Salzer, M. 1998).

${ }^{20}$ Essa aparente hesitação (no contexto comercial e predatório) entre as posições, não exatamente equivalentes de freguês e empregado, terá de ser analisada no contexto dos rituais ihinika e amamajo, em relação às concepções paumari sobre o corpo e a pessoa.

${ }^{21}$ Sobre a questão da compensação da predação através da domesticação de animais, ver Descola 1999 e Erikson 1984.

22 Os Jobiri são provavelmente os Jubery ou Juberis descritos pelos viajantes como um subgrupo Puru-puru. Para os Paumari, hoje, os Jobiri eram seus guerreiros, 
seu exército, e o pertencimento a essa categoria guerreira era hereditário (transmitindo-se tanto patri como matrilinearmente).

${ }^{23}$ Os Apurinã são Arawak e são os mais próximos vizinhos dos Paumari. Atualmente, os outros vizinhos próximos são todos grupos arauá, culturalmente e lingüisticamente mais próximos dos Paumari.

${ }^{24}$ A informante faz referência aqui ao ritual ihinika, à introdução do abonoi dos alimentos no abonoi da criança. O barijaro é uma substância vegetal mágica usada nesse ritual e administrada em vários momentos à criança. Ela deve proteger os abonoi dos alimentos que vêm constituir seu próprio abonoi (alma-corpo).

${ }^{25}$ Hoje ocupado pelos Apurinã que compartilham a Terra Indígena do Lago Marahã com os Paumari.

${ }^{26}$ Os Joima são sempre descritos como mais escuros que os Paumari. Neste contexto, o termo usado em português "bronzear-se" pode também significar "camuflar-se".

${ }^{27}$ A evocação destas rodas coincide com uma parte do ritual paumari de puberdade das moças (Amamajo).

${ }^{28}$ Os Americanos são altos, têm olhos claros e pele avermelhada. Esta última característica seria o sinal de sua predileção pela carne humana. Nota-se que o safini kapamoarihi, o patrão-sol, tem essas mesmas características e é apontado como responsável por várias doenças que provocam febre muito alta. Portanto, comer carne humana é atributo de pessoas demasiadamente escuras ou avermelhadas. Assim, a ingestão de alimentos tem repercussões corporais visíveis. Da mesma maneira, a ingestão excessiva de banha de peixe provocaria a coloração da plumagem dos pássaros e também a pinta, manchando a pele dos Paumari. Os Paumari, mais uma vez, encontramse do lado dos igitha, pássaros, mas também animais familiares, por excelência.

${ }^{29}$ Os marginais mais perigosos vêm de Porto Velho e estão na famosa prisão de segurança máxima de Urso Branco, da qual fogem, de fato, regularmente. Há marginais em todas as cidades, em Lábrea, Tapauá e Manaus. Mas eles não parecem representar um perigo tão real quanto os que vêm de Porto Velho.

${ }^{30}$ Perguntavam-me o que eu faria se encontrasse com ela, pois ela não falava nem paumari nem português. 
${ }^{31} \mathrm{O}$ fato de poder assustar a antropóloga também entra, provavelmente, em jogo nesses momentos. Mas o efeito desses boatos é coletivo, e todos os levam a sério.

32 Sem dúvida, trata-se aqui de Manoel Urbano da Encarnação, que viajou pelo Purus na segunda metade do século XIX. Foi um de seus desbravadores e um "fundador de povoados" (Cunha 1960 [1906]:80).

${ }^{33}$ Os Jara eram, até então, temidos pelos Paumari pois, segundo contam os relatos, vinham para matá-los e devorá-los. Os xamãs defendiam os Paumari transformando os invasores em aves (igitha raboki) ou mandando insetos devorar suas provisões.

${ }^{34}$ No final do relato, Orobana adota uma criança paumari e a leva para Manaus, onde esta aprende a língua portuguesa (jara athini).

${ }^{35}$ Ver nota 29. 


\section{Referências bibliográficas}

BROWN, Charles Barrington e LIDSTONE, William. 1878. Fifteen thousand miles on the Amazon and its tributaries. Stanford, London. 520 p. CHANDLESS, William. 1949 [1869]. "Notas sobre o rio Purus". Arquivos da Associação Comercial do Amazonas, 9(3):21-29;10(3): 29-40.

CHAPMAN, Shirley e SALZER, Meinke. 1998. Dicionário bilíngüe nas línguas paumarí e portuguesa e perfil gramatical. Porto Velho: Sociedade Internacional de Lingüística.

COUTINHO, João Martins da Silva. 1863. "Relatório da exploração do rio Purú". In: Relatório da Repartição dos Negócios d'Agricultura Commercio e Obras Publicas (1864), apresentado à Assembléia Geral Legislativa na 3a sessão da 12a Legislatura, em 15 de maio de 1865. Anexo 0:5-96.

CUNHA, Euclides da. 1960 [1906]. O rio Purus. Rio de Janeiro: SPVEA. Coleção Pedro Teixeira. 95p.

CUNHA NEIVA, Tania Maria. 1975. "Alguns dados sobre o grupo paumary". Rio de Janeiro: Museu do Índio / Fundação Nacional do Índio, Ms.

DELEUZE, Gilles. 1967. Présentation de Sacher-Masoch. Le froid et le cruel. Paris: Les Editions de Minuit.

DESCOLA, Philippe. 1999. "Des proies bienveillantes. Le traitement du gibier dans la chasse amazonienne". In: F. Héritier (dir.), De la violence II. Paris: Odile Jacob. pp. 19-44.

ERIKSON, Philippe. 1984. "De l'apprivoisement à l'approvisionnement: chasse, alliance et familiarisation en Amazonie amérindienne". Techniques et Cultures, 9: 105140.

FAUSTO, Carlos. 2002. "Banquete de gente: comensalidade e canibalismo na Amazônia". Mana. Estudos de Antropologia Social, 8(2):7-44.

KROEMER, Günter. 1985. Cuxiuara: o Purus dos indígenas. Ensaio etnohistórico e etnográfico sobre os índios do médio Purus. São Paulo: Loyola. 172pp.

LABRE, Antonio Rodrigues Pereira. 1872. Rio Purús. Noticia. Maranhão: Typ. do Paiz.

POLLOCK, David. 1985. "Looking for a sister: Culina siblingship and affinity". In: K. Kensinger (ed.). The sibling relationship in Lowland South America. Working Papers on South American Indians, 7:8-15.

VILAÇA, Aparecida. 2002. "Making kin out of others in Amazonia". Journal of the Royal Anthropological Institute, 8(2):347-365.

VIVEIROS DE CASTRO, Eduardo. 1996. "Os pronomes cosmológicos e o perspectivismo ameríndio". Mana. Estudos de Antropologia Social, 2(2):115-144 


\section{Resumo}

Este ensaio etnográfico é uma análise da sociologia relacional paumari. Ele parte da observação segundo a qual toda a relação estabelecida entre um Paumari e outro ser é rapidamente definida em termos comerciais. Mas essa "mercantilização das relações" vai além dos fatos cotidianos, pois figuras como o "patrão" e o "empregado" são encontradas em vários níveis da cosmologia paumari. Minha hipótese consiste em pensar que, para os Paumari, a relação comercial é a relação por excelência. Tento, então, mostrar que em um mundo povoado por seres potencialmente sociais, os Paumari concebem a si próprios como ocupando preferencialmente a posição de presa/animal doméstico, que corresponde, em muitos aspectos, à posição de freguês/empregado, o que deve ser pensado em relação à história da região e às três dimensões básicas da economia simbólica da Amazônia.

Palavras-chave Paumari, Predação, Familiarização, Comércio, Patrões

\section{Abstract}

This ethnographic essay is an analysis of the Paumari relational sociology. It proceeds from the observation that any relationship established between the Paumari and other beings is quickly defined in commercial terms. However, this 'commercialization of relationships' extends far beyond the everyday, since figures such as the 'boss' and the 'employee' are encountered at various levels of Paumari cosmology. My working hypothesis is that, for the Paumari, commercial relations are the relations par excellence. I attempt to show, therefore, that in a world populated by potentially social beings, the Paumari imagine themselves to occupy (by preference) the position of domestic prey/animal or pet. In turn, this position corresponds in many aspects to the position of guest/employee - a correlation which becomes clearer when examined in relation to the region's history and the three basic dimensions of the Amazonian symbolic economy.

Key words Paumari, Predation, Familiarization, Trade, Bosses 